\title{
Islamism and Jihadism: The Transformation of Classical Notions of Jihad into an Ideology of Terrorism
}

\author{
DAVID COOK
}

Rice University, Houston, Texas

ABSTRACT Contemporary jihad is the lineal descendant of classical jihad theory as modified by contemporary radical Islam. It has expressions in both Sunni and Shi 'ite Islam, but differs from the classical material in that the targets allowable for jihad are not states but smaller groups or even individuals. The article traces the history of this development.

\section{Classical Jihad Theory}

Classical Muslim jihad theory is based upon a combination of Qur'anic selections, hadiths (traditions ascribed to the Prophet Muhammad), legal discussions based upon the hadith literature and formal treatises dealing with jihad. Each one of these components has its place. The Qur'anic materials are related to the experiences of Muhammad and the first Muslim community, who after the immigration to Medina (the hijra, 622), needed to establish themselves in the oasis town. Most of the major battles that Muhammad and the Muslims fought during the eight years following the hijra are alluded to in the Qur'an, with extensive discussion of tactics, the theological importance of these battles, questions of the reward of martyrs and other issues. Because not all of these battles were victories for the Muslim community, it is possible to find coverage for military outcomes ranging from defeat to stalemate to Pyrrhic victory to outright victory.

And yet the word 'jihad', so emblematic of later Muslim warfare, only occurs with a military significance rarely inside the Qur' an. ${ }^{1}$ While the warfare carried out by the Prophet Muhammad and the Muslims has all the hallmarks of what would later be called 'jihad' - warfare with divine sanction - it is to the great Muslim conquests that followed 634, and changed the face of the Middle East and North Africa irrevocably, that we must turn for the crystallisation of jihad. It is from this period lasting until approximately 740 that we begin to find the mythology of jihad develop. Because the materials were not written down for a further 50-100 years afterwards, we have to reconstruct the development of this mythology - primarily on the basis of the hadith literature (mostly written down during the ninth century mostly) and the jihad literature.

The hadith literature is vast, but most collections, and certainly the primary ones (the so-called 'canonical' collections), contain a section on jihad. These selections consist of sayings ascribed to Muhammad enjoining jihad and declaring its limitations, and pseudo-historical snippets from his battles or battlefield injunctions 
liberally intermixed with passages from the Qur'an relevant to the subject. Strictly speaking, the materials in the hadith literature are not sufficient for a comprehensive development of doctrine on the subject, but they are enough to provide the jurisprudents who organised them, starting in the later ninth century and continuing on until modern times, with material. As is usual with the hadith literature, some of the traditions are useful as concise statements for fighters or as slogans, but many of them are either irrelevant or too lengthy for practical use.

For this reason it is easy to see why the jihad literature developed alongside the hadith materials. The Kitab al-jihad of 'Abdallah b. al-Mubarak (d. 797) is the earliest example of this literature, and the first definitive time when the word 'jihad' is used in its popular Muslim connotation. ${ }^{2}$ It contains hundreds of sayings, tactical advice, descriptions of martyrs' rewards and slogans that are very useful on the battlefield. Appropriately, none of these are particularly long, and most are quite clear and to the point. Ibn al-Mubarak was himself a volunteer fighter, and utilised the spiritual and political prestige he gained by fighting the Byzantines (almost single-handedly) to embarrass the 'Abbasid government into following him. Essentially, Ibn al-Mubarak was one of the first Muslims who was able to use the title of 'defender of Islam' to challenge the establishment - a paradigm copied today by radical Muslims. Later jihad literature flourished at the time of the Crusades and a number of the authors prominent at that time, such as al-Sulami (d. 1261) ${ }^{3}$ and Ibn al-Nahhas al-Dumyati (d. 1411), ${ }^{4}$ followed in the footsteps of Ibn al-Mubarak.

The legal literature of jihad is much more complicated than any of these first three genres. First of all, like with the hadith literature, the legal literature of Sunni Islam is vast and discussions on jihad constitute only one small part of it. Many of the jurisprudents, however they disliked it, were effectively tailoring their discussions on jihad to either regions (such as North Africa, where jihad against the Christians of Spain was an ever-present reality, or India) or to dynasties such as the 'Abbasids, the Ayyubids or the Mamluks. Jihad, as expressed by the jurisprudents, was a regulated type of warfare. It had to have the sanction of the imam (or caliph), who was the representative of God, and be for a specific purpose. According to the jurisprudents, jihad is a process that begins with the summoning of the enemy to Islam, and either leads to Muslim victory, in which case the enemy is either killed, enslaved or accepts the protection (dhimma) of the Muslims, or to a tactical ceasefire (hudna). There is little discussion as to what Muslims should do in case of an outright or catastrophic defeat.

Jihad is divided into three categories according to these classical formulations: jihad of the hand (or the sword), which was military in nature; jihad of the tongue, which involved the reproof of an unjust ruler or corrupt society; and jihad of the soul, developed mostly by the Sufis, that involved waging an internal struggle against one's lower soul. For the jurisprudents, there was extensive discussion concerning the jihad of the hand, which was described as being incumbent upon part of the community at all times (for offensive attacks), but upon the whole community at others (when it was defensive). However, the jihad of the tongue was problematic because of the fact that it could be used as a device against elites, and was part and parcel of the activist doctrine of al-amr bi-l-ma' $r u f$ wa-l-nahi 'an al-munkar (enjoining the good and forbidding the evil). ${ }^{5}$ Both jihad of the tongue and jihad of the soul were comparatively unimportant in the classical period. While one finds examples of them in the literature, discussions concerning them were peripheral to the Muslim community overall. ${ }^{6}$ 
Probably the most difficult discussion that exercised the classical Muslim jurisprudents was the question of who was a legitimate target in jihad. At first, the lines were clear. Enemy combatants (non-Muslims) were legitimate; nonMuslim non-combatants (women, children, elderly, monks and religious figures) were not. However, quickly jihad began to be utilised by Sunnis, especially against Muslim communities who were outside the mainstream, such as Shi'ites and Kharijites, and later others. For this reason, the term 'jihad' became expanded immensely by the middle of the classical period (eighth to fifteenth centuries), and it was not unusual during a 'jihad' to find Muslims fighting together with non-Muslims against other Muslims.

The Shi 'ite experience was quite different. Supporting as they do the rights of the Prophet Muhammad's family to rule the Muslim community, Shi 'ites historically were compelled to fight in order to obtain these rights. Because Shi'ites have always been a minority among the Sunni masses, they have not always participated in jihad against non-Muslims, but have instead themselves been the targets of Sunni jihads. This trend began with the paradigmatic Shi'ite martyr, the Prophet Muhammad's grandson al-Husayn (killed 680). Al-Husayn was killed at Karbala' in southern Iraq, while leading a small group of his immediate family and supporters, by troops who supported the Umayyad government. This tragic scene was duplicated dozens of times during the early Muslim period, as members of the Prophet Muhammad's family and their supporters attempted to revolt against and seize power from the Sunni governments. While Sunni jihad theory emphasises the triumphal process of conquest from non-Muslims in which martyrs either gain victory or paradise, Shi'ites emphasise the tragic and mournful quality of perpetual (but noble) defeat. Sunni jihad harks back to the Prophet Muhammad's ultimately successful conquest of Mecca in 630 and the founding of the Muslim community, while Shi 'ite jihad commemorates the unjust slaughter of Muhammad's descendents and looks forward to the time when the Mahdi (the Muslim messianic figure) can take vengeance for these wrongs and establish a righteous state. ${ }^{7}$

\section{Contemporary Mainstream Jihad}

For the most part jihad theory fell fallow after the great anti-colonialist jihads of the nineteeth century (although in isolated places such as Somalia these continued on into the twentieth century). The ideology which won independence for the Muslim world from European colonialism was not that of jihad, but rather usually some mixture of nationalism and socialism. Occasionally there were religious figures who participated in these struggles, such as the proto-Palestinian (although Syrian by birth) 'Izz al-Din al-Qassam (d. 1936) ${ }^{8}$ and the Algerian 'Abbas Madani, ${ }^{9}$ but these were few and far between. Elites within the Muslim world either crushed political Islam (mainly in the form of the Muslim Brotherhood) during the 1940s and 1950s or in some cases co-opted it.

However, with successive defeats by Israel that destroyed the legitimacy of secular nationalistic regimes during the 1960s, jihad theory began to be revived. In its most mainstream form, this meant publications of fatwas (legal opinions) by respected religious figures and institutions (such as al-Azhar in Cairo) declaring that fighting Israel was indeed a legitimate jihad. However, there were some problems with these proclamations. First of all, in general Muslim governments did like to have jihad-style rhetoric used extensively, if only because many of the 
elites were influenced either by socialism or other Western ideologies or because they were not Muslim (usually Christian). Second, jihad rhetoric gave very little room to negotiate in warfare. The style of warfare promoted in Sunni jihad was a 'victory or martyrdom' warfare, which was not the style of a secular government, and did not allow for the use of specifically Islamic tactics derived from the classical religious literature.

However, this fact does not mean that mainstream Sunnis have avoided discussion of jihad during the period following 1970. Although they were (unjustly, in my opinion) accused by radical Muslims of ignoring jihad, ${ }^{10}$ prominent religious figures such as Mahmud Shakir (Syrian), ${ }^{11}$ Muhammad 'Izzat Darwaza (Palestinian), ${ }^{12}$ Hasan Ayyub (Egyptian), ${ }^{13}$ Dr Muhammad Ramadan Sa'id al-Buti (Syrian), ${ }^{14}$ Muhammad Matawalli Sha 'rawi ${ }^{15}$ and Dr Salah Basayuni Rislan (Egyptian) ${ }^{16}$ and others wrote on jihad. However, while many of these writers were concerned with the issue of jihad against Israel, especially by the Palestinians, they are all characterised by attempts to limit jihad in some way, and in that way to follow the classical jihad heritage. Jihad for them is a form of warfare that is ordained by religious authority, most specifically the 'ulama (in lieu of a caliph) and can only be waged against external enemies such as the Israelis.

The above tracts, however distinguished their authors might be, are usually not very comprehensive. This is not the case with regard to Muhammad Khayr Haykal's 1993 treatise al-Jihad wa-l-qital fi al-siyasa al-shara 'iyya, ${ }^{17}$ which gives a complete treatment of the subject and considers a number of unusual contemporary problems not mentioned by previous writers. These include the question of women fighting in jihad, the use of weapons of mass destruction in jihad, and the issue of when jihad is forbidden or what to do when the Muslims lose a jihad. Haykal is moderate in his opinions, and gives a balanced sense of what the classical and contemporary legal opinion is on each topic.

Following the rise of radical Islam as an intellectual force in the 1980s and especially the 1990s, more of the mainstream 'ulama wrote against the excesses of their methods of fighting. However, it is still possible to discern mainstream support for extreme tactics against Israel and in some cases against India (by Pakistani 'ulama). Probably the most obvious example of this support is the question of the use of suicide attacks. Classical Muslim jihad theory did not allow for the use of suicide attacks except when there was some type of benefit for the Muslims. Even such a broad-ranging author as Ibn al-Nahhas al-Dumyati (mentioned above) could not see such benefit, and indeed it is difficult to understand what a suicide attack in the pre-modern world (prior to the discovery of explosives) could accomplish that an ordinary military attack could not.

As we will note below, Shi'ites used suicide attacks and suicidal mass wave operations, but Sunnis until the middle of the 1990s did not. With the first suicide attacks by Hamas and Islamic Jihad against Israel in 1994 (reprisals for the Hebron massacre of early 1994), these attacks became gradually morphed into 'martyrdom operations'. As a result of the initial popularity of the al-Aqsa Intifada (2000-2005), martyrdom operations were embraced by many 'ulama in the mainstream. However, there were always those such as Hasan Ayyub (above), the Syrian Nasir al-Din al-Albani and the Saudi Ibn 'Uthaymin who rejected such attacks as being nothing other than suicide or being detrimental to the image of Islam. ${ }^{18}$

After the attacks of 11 September 2001 many mainstream 'ulama recanted their general support for martyrdom operations, and while affirming their legitimacy in attacks against Israel (because of the inferior position of the Palestinians), they 
tried to limit their use severely. This tendency is the dominant characteristic of the contemporary mainstream Sunni Muslim 'ulama position vis-à-vis jihad: it should be regulated closely along the classical lines, it should be focused on an obvious enemy (such as Israel) by consensus, and it should be presented to the outside world in Marxist, liberationist terms, not in purely Islamic terms. All of these characteristics are completely rejected by radical Muslims.

\section{Anti-governmental Jihad}

At the same time as mainstream Islam was rediscovering jihad, radical Muslims outside the mainstream were as well. Radical Islam is an ill-defined movement embracing Muslims who not only call for the restoration of shari' $a$ in society (something that theoretically all Muslims support) but seek to radically reshape both the shari' $a$ and the society. In general they are hostile to Sufism and to governmentally-supported religious elites. Usually they embrace Western science and technology, while of course strongly rejecting Western political hegemony and cultural norms.

Although it is possible for some elements of radical Islam to support mainstream calls for jihad, in general by the mid-1970s there was a strong consensus among these groups that fighting must be on the basis of Islam, and nothing else. This is best expressed by 'Abd al-Salam Faraj's treatise, al-Farida al-gha'iba:

Muslim blood will be shed in order to realize this victory. Now it must be asked whether this victory will benefit the interests of an Islamic State? Or will this victory benefit the interests of infidel rule? It will mean the strengthening of a state which rebels against the Laws of God ... these Rulers will take advantage of the nationalist ideas of these Muslims in order to realize their un-Islamic aims ... Fighting has to be done (only) under the Banner of Islam and under Islamic Leadership. ${ }^{19}$

Because radical Muslim groups had defined the necessity of fighting solely for an Islamic state, they had to first of all transform their countries into Muslim states. This dilemma necessitated development of the jihad of the tongue, the jihad against corrupt and tyrannical rulers. Throughout the 1950s and 1960s radical Muslim theorists had already developed the idea that contemporary Muslim societies were in a state of apostasy, and therefore that apparent Muslims could be fought and killed in order to establish a shari 'a state. That willingness to label apparent Muslims as infidels (takfir) separated radicals out from other more mainstream Muslim groups.

Takfir proved to be a slippery slope for radical Muslims, as throughout the 1990s and the first decade of 2000 they began to globalise it more and more. In practice this global takfir enabled radical Muslims to attack their societies and kill apparent Muslims indiscriminately under the pretext that such attacks were justified. Not surprisingly takfir proved to be very unpopular, and indiscriminate attacks enabled otherwise embattled secular regimes in Algeria and Egypt to demonise the radicals, and ultimately to marginalise them.

For the most part the anti-governmental jihad discussions are consumed with the question of what are the legitimate targets of these groups. Most agree that the governments and their leaders are apostate and are responsible for denying the implementation of shari' $a$ within Muslim majority countries. But the fact is that, 
for the most part, these higher governmental officials are not easy targets for the anti-governmental jihad, as they are protected by security forces. This fact raises the question of whether the security forces (army, police, secret agencies, etc.) are legitimate targets. Discussions concerning this question turn on whether the security forces are volunteer or conscript, and in some cases whether they carry out their tasks with genuine or substandard fervour. In general, the answer to these questions has been that the security forces are indeed legitimate targets. ${ }^{20}$

Beyond the security forces are a whole range of other forces that prop up secular regimes, including economic factors (trade and tourism, and in some cases the oil industry) and cultural factors (entertainers who distract the masses from Islam, writers who write books and articles that are sometimes against the radical interpretation of Islam). Economic factors weigh heavily in a country such as Egypt, which is dependent upon tourism for the livelihoods of many of its people (directly and indirectly). And then there are the families of all of these people - are they possible targets as well $?^{21}$

And lastly there are true innocents, who by no stretch of the imagination can be considered to be participants in any conflict. Probably the best known case of an innocent being killed was the little girl Shayma' 'Abd al-Halim, who was killed when the Egyptian Islamic Jihad tried to assassinate the prime minister 'Atif Sidqi in 1993. The prime minister escaped from this attempt unhurt, but a large number of school-girls were injured and Shayma' was killed. This case is paradigmatic of a public relations disaster for radicals, as it raised the following question: if they were trying to establish a just Muslim state, why did a little girl have to die? The answer given at the time by Sayyid Salah, one of the leaders, that he was 'sorry for the death of this little girl, but the jihad must not cease', ${ }^{22}$ is problematic because of its cold-bloodedness. Ultimately, it was 'mistakes' like this one that caused the anti-governmental jihad in Egypt to fail.

\section{Apocalyptic Global Jihad}

Concurrent with the development of anti-governmental jihad in Egypt, the jihad against the USSR in Afghanistan was beginning. Although objectively speaking the Arab and other Muslim volunteers mainly based in Peshawar (Pakistan) did not contribute significantly to the ultimate victory of the mujahidin over the communist regime (in 1992), the experience they lived through was transformative. Unlike all other wars (including the ones against Israel), the Afghan jihad was (at least from the perception of the foreign mujahidin) a pan-Islamic one. Muslims from all over the world participated in a victorious struggle against one of the world's two superpowers and defeated it, causing it to actually collapse a few years later.

The architect of this pan-Islamic vision was 'Abdallah 'Azzam, a Palestinian radical who, despairing of progress in the struggle against Israel, had identified the Afghan jihad as a place where fighters could gain experience. 'Azzam's goals shifted over the years: at first he used slogans like 'the road to al-Quds [Jerusalem] leads through Kabul', ${ }^{23}$ but gradually he began to see the possibilities for the foundation of an actual Islamic state in Afghanistan and Pakistan. One of the problems with the anti-governmental radicals above was the fact that they lacked a geographic base. While in certain cases, like in Algeria or Lebanon, the terrain favoured guerrilla groups, in others such as Egypt it was difficult for the mujahidin to establish themselves. It goes without saying that virtually all 
governments were either hostile to the aspirations of anti-governmental mujahidin or could be pressured to curtail their support (in the case of the Sudan). Thus, 'Azzam recognised that the mujahidin needed a base, in Arabic al-Qa'ida, in order to thrive.

Such a base could only be established in a failed state and must have a militant population made ready for perpetual jihad by a conflict against infidels. Hence 'Azzam began to preach a salvationist type of jihad during his later years (1986-1989), in which the Muslim world would reconquer all of the territories that were once Muslim. ${ }^{24}$ According to 'Azzam, because of the exigencies of the present situation the entire Muslim world is in a state of civilisational defensive jihad. This means that it is incumbent upon each and every Muslim - male and female - to participate in the jihad. 'Azzam also stressed that every Muslim who does not fight in the jihad is not a true Muslim. Just as with the issue of takfir mentioned above, for 'Azzam and other globalist apocalyptic mujahidin, waging jihad served as the primary criterion for deciding whether one was or was not a Muslim.

When one looks at the list of territories that 'Azzam said needed to be reconquered, including all of India, Central Asia, most of Russia, south-eastern Europe (the Balkans), southern Italy and Spain, it is clear that this jihad would be largescale and lengthy, and would encompass much of the world. If such a war were to be ignited it would be impossible for most Muslims to live peaceful lives, as their homes would be either bases for attacks against the infidels or subject to attack themselves.

This type of globalist apocalyptic jihad relies upon the perception that the entire non-Muslim world is currently participating in a campaign of extermination against the Muslims. The most useful tradition supporting this idea is the following:

The Messenger of God said: The nations are about to flock against you [the Muslims] from every horizon, just as hungry people flock to a kettle. We said: O Messenger of God, will we be few on that day? He said: No, you will be many as far as your number goes, but you will be scum, like the scum of the flash-flood, since fear will be removed from the hearts of your enemies, and weakness (wahn) will be placed in your hearts. We said: O Messenger of God, what does the word wahn mean? He said: Love of this world and fear of death. ${ }^{25}$

This tradition - known as the hadith of Thawban - affirms that Muhammad prophesied the time when Muslims would be under attack by the entire world, and yet still avoid jihad, and be afraid of death. For radical Muslims, and especially apocalyptic globalist jihadis, this tradition is key to legitimising their stance.

In general, al-Qa'ida and its ideological allies have contributed to the following methodology of jihad. First, they have taken tactics that mainstream Arab Muslim religious thought had legitimised for the Palestinians and applied them to fighting every foreign enemy (the USA, Russia, India, and others). Second, they have made jihad the major criterion for deciding whether someone is a Muslim or not. Third, they have made the distinction between defensive and offensive jihad meaningless, to the point where if jihad were waged according to their pronouncements it would be eternal.

Like their friends in the anti-governmental jihad camp, apocalyptic global jihadis are in general quite lonely. They cannot count on the support of any government 
(other than that of the Taliban in Afghanistan), and their use of indiscriminate violence, especially suicide attacks, has made them odious to most of the Muslim world. Although their general goals - the establishment of a shari' $a$ state and the unification of the Muslim world under the rule of a caliph - command some passive support, their methods have driven even this passive support down considerably during the past years.

\section{Changing Shi‘ite Conceptions of Jihad}

As noted previously, Shi 'ites did not have the collective history of victory in jihad that the Sunnis did. At the time of the Islamic Revolution in Iran (1977-1979), in general Shi'ite discussion of jihad was limited. This fact changed dramatically with the Iraqi invasion of Iran in 1980, when Iran was forced to fight for its land against what it perceived as a coalition of Arabs and Western countries. During the initial stages of this war, dramatic tactics were required involving suicidal human wave assaults against the Iraqi positions. Because of the heritage of martyrdom inherent in Shi'ism, these suicidal attacks were not ideologically problematic. $^{26}$

The rise of the Islamic Republic in Iran also was a stimulant for the appearance of radical Shi'ite groups in other places, such as Lebanon (Amal and Hizballah) and Pakistan (Tehrik-i Ja'fari). Hizballah was first pitted against Western armies located in Beirut, and in order to expel them it used suicide attacks against the US and French forces with great success. ${ }^{27}$ After 1983 Hizballah turned to the more difficult local enemy, Israel, which was then occupying most of southern Lebanon. Initially Hizballah used suicide attacks against Israel with the same level of success previously achieved against the USA and France. However, gradually through the 1980s a law of diminishing returns prevailed, as the Israelis were able to develop tactics that made suicide attacks pointless. Virtually no Hizballah suicide attacks are recorded after 1989 (with the exception of the one in Argentina against a Jewish Centre in 1994). ${ }^{28}$

Hizballah and other Shi'ite organisations in Pakistan, and then later in Iraq (after 2003), have tended to use standard guerrilla tactics against their enemies, and have carefully avoided the use of suicide attacks. This avoidance is most obvious in Iraq and Pakistan, where Sunni radicals have carried out dozens (in Pakistan) and hundreds (in Iraq) of suicide attacks against Shi'ite civilians, and desecrated their religious sanctities. But probably because of the hierarchical nature of Shi 'ite Islam, there has been no movement to declare Sunni radicals infidels (after the manner of the latter's takfir mentioned above) ${ }^{29}$ Nor has there been extensive development of new tactics of jihad among Shi'ites. Again, this fact probably has to do with the lack of an authority void in Shi'ism which is the principal problem of Sunni radicals. Thus, while Shi ite radicals have been much more successful from a political point of view than their Sunni counterparts, they have displayed little leadership in the field of jihad theory during the recent past.

\section{Tactics and Strategy}

Muslim radicals, especially Sunnis, have been at the forefront of the development of new tactics and strategy for jihad during the past 30 years. If a common theme can be discerned in all of these developments, it is the desire to develop tactics that will win, will highlight the sacrifices that the mujahidin have and are making 
on behalf of the Muslim community, and will gain them the prestige they crave so that they can transform their societies. However, finding a balance between these different imperatives has proven to be difficult.

The major tactic used by radical Sunni Muslims is the suicide attack. Indeed, while radical Sunni Muslims did not pioneer this tactic - even in the Muslim world, where as we have seen it was associated with Hizballah and Shi'ites - their development of it and excessive usage of it has made it their signature style of attack. Indeed, in arenas such as Iraq where there are multiple groups fighting, with varied ideologies, only those groups who are anti-governmental jihadis (employing takfir) or from the apocalyptic globalist jihadi camp use suicide attacks. Other groups specialise in conventional guerrilla attack methods such as sniper attacks, road-side bombings or even full-scale military attacks. For these, even religious groups do not require legitimisation.

Suicide attacks or martyrdom operations are legitimised by using the analogy of the legal category of 'the single fighter who charges a larger number' that appears in the classical literature, and is approved as long as there is benefit in it for the Muslims. ${ }^{30}$ Because this fighter is unlikely to survive such an attack, contemporary fatwas state that martyrdom operations are legitimate. The question of the innocents who will be killed in such attacks is dealt with by referring to the majaniq (mangonels) which were used by the Prophet Muhammad against the city of Ta'if in 630. Because the mangonel is a spring-loaded, rock-hurling instrument that cannot discriminate between fighters and innocents as its payload careens down into a city or fortress, it is held that explosions are also legitimate, even though one cannot know who will be killed as a result of them.

Additionally, both anti-governmental jihadis and globalists have vastly changed the definition of a legitimate target. While classical jihad theory emphasised a number of categories of people, such as women and children, who were sacrosanct, contemporary jihad theory states that participation in the mechanisms of modern states confers upon their citizens responsibility for the actions of their governments because of their voting and payment of taxes. If someone participates in these activities, then they are legitimate targets for reprisals in response to the actions of their government. Muslims who live in non-Muslim countries and are killed because of martyrdom operations should not have been there in the first place, and are often labelled as apostates on the basis of the argument that they are contributing to or supporting an infidel regime which is oppressing the Muslims in other places in the world. And of course the Algerian antigovernmental jihad had already developed the argument that the families of apostates are fair game as well.

However, radical Muslim groups in Iraq have been willing to develop other extreme tactics, such as beheading, ${ }^{31}$ kidnapping ${ }^{32}$ and the mutilation of bodies. ${ }^{33}$ Each one of these types of tactics has been discussed, usually on-line, and then carried out on the field. Al-Zarqawi pioneered the extensive use of beheading via the internet as a means by which the Iraqi jihad could be publicised, and nonMuslims (and apostates) terrorised. However, just as with other controversial tactics used by jihadis, beheading eventually has led to bad publicity for them, and has been largely abandoned.

With regard to weapons of mass destruction, the principles already laid down by the discussion on suicide attacks are the basis for approval. The well-known Saudi radical cleric Nasir al-Fahd penned a fatwa authorising the use of weapons of mass destruction, again using the mangonel and the tax and voting 
arguments listed above. ${ }^{34}$ Although the mujahidin in Iraq have attempted to use chlorine gas in order to magnify the number of casualties, they have found that utilising gas is difficult and that the numbers of casualties have not justified the effort. There are also indications that they may have abandoned this tactic, perhaps under pressure from al-Qa'ida Central's leadership, because it further alienated them from the Sunni Iraqi population whose continued support they depend upon.

All-in-all, the mujahidin have made a maximum effort to expand and develop classical jihad theory. However, their success in utilising the new methodologies has been quite mixed and in some cases negative for them. There is little popular support among the Muslim community for fighting or killing methods that could possibly be directed against Muslims, as has all too often been the case in the recent past. In the end, the mujahidin gain the most political and religious support when they portray themselves as underdogs who courageously fight against enemies of the Muslims under tremendous odds. The moment that the mujahidin turn their violence against Muslims, they begin to lose popularity and ultimately become marginalised.

\section{Conclusions}

Contemporary jihad theory uses all of the same terms as classical jihad theory. However, the emphasis in contemporary jihad, at least as it is manifested among radical Muslims, is upon functionality rather than legality. Increasingly, the discussions concerning jihad are discussions about the nature of authority in Sunni Islam (after the abolition of the caliphate in 1924). Whereas traditionally authority in Sunni Islam was held by the 'ulama, even in matters of jihad, today few of the ulama are actively members of radical groups. Those few radical 'ulama are mostly in prison or are far from the field of battle. ${ }^{35}$ Mujahidin increasingly see themselves as the arbiters of what is right and what is wrong in jihad, and feel that their position as the staunchest defenders of Islam gives them the authority that the 'court' 'ulama have abdicated.

For this reason, although radical fighters fight foreign powers (the USA, Israel, Russia, India, and others), their true target is still the reform of Islam and the reconstituting of Muslim society. Jihad and the legitimacy it confers upon the fighter in the eyes of the Muslim world is but one means by which this authority can be grasped.

As noted above, while the mujahidin have been at the forefront of the development of new jihad law, the acceptance of their law is very open to question. Few of the 'ulama identify with the mujahidin, and many of their rulings are open to the accusation that the latter are finding what they want to find in the classical material, and making exceptions into the rule. For this reason it is questionable whether the mujahidin in the future will be able to gain the legitimacy of consensus for their ideas.

\section{Notes}

1. For a thorough discussion, see Jane Dammen McAuliffe (ed.), Encyclopedia of the Qur'an (Leiden: E.J. Brill, 2003), s.v. "jihad" (Ella Landau-Tessaron).

2. Ibn al-Mubarak, Kitab al-jihad (ed. Nazih Hammad) (Beirut: Muhammad 'Afif al-Zu'bi, 1971).

3. al-Sulami, Ahkam al-jihad wa-fada'iluhu (ed. Ayyad Khalid al-Tibba') (Beirut: Dar al-Fikr alMu'asir, 1996). 
4. Ibn al-Nahhas al-Dumyati, Mashari' al-ashwaq ila masari' al-'ushshaq fi al-jihad wa-fada'ilihi (eds Durish Muhammad 'Ali and Muhammad Khalid Istambuli) (Beirut: Dar al-Basha'ir al-Islamiyya, 2002).

5. Michael Cook, Commanding Right and Forbidding Wrong in Islamic Thought (Cambridge: Cambridge University Press, 2000), chapters, 3, pp.18-19.

6. Michael Cook, Understanding Jihad (Berkeley, CA: University of California Press, 2003), chapter 2.

7. Etan Kohlberg, "The Development of the Imami Shi'i Doctrine of jihad", Zeitschrift der Deutschen Morgenländischen Gesellschaft 126 (1976), pp.64-86.

8. Bassam al-'Asayli, Thawrat al-shaykh 'Izz al-Din al-Qassam (Tunis: Dar al-Baraq, 1991).

9. Ibid, ed., Jihad sha'b al-Jaza' ir (Beirut: Dar al-Nafa'is, 1982), 13 vols.

10. Implicit in the title of 'Abd al-Salam Faraj's 1981 booklet, al-Farida al-gha'iba.

11. al-Jihad fi sabil Allah (Riyad: Maktabat al-'Ubaykan, 1999).

12. al-Jihad fi sabil Allah (Sa'da: al-Maktaba al-'Asriyya, 1988, reprint).

13. al-Jihad wa-l-fida'iyya fi al-Islam (Beirut: Dar al-Nadwa, 1981); Fiqh al-jihad fi al-Islam (Cairo: Dar al-Salam, 2002).

14. al-Jihad fi al-Islam (Beirut: Dar al-Fikr al-Mu`asir, 1997); trans. Munzer Absi, Jihad in Islam: How to Understand it and Practice it (Beirut: Dar al-Fikr al-Mu`asir, 1995).

15. al-Jihad fi al-Islam (Cairo: Maktabat al-Turath al-Islami, 1998).

16. al-Jihad fi al-Islam (Cairo: Dar al-`Asriyya al-Sa`udiyya, 2005).

17. al-Jihad wa-l-qital fi al-siyasa al-shara 'iyya (Beirut: Dar al-Barayiq, 1993), 3 vols.

18. For discussion see Nawaf al-Takruri, al-'Amaliyyat al-istishhadiyya fi al-mizan al-fighi (Damascus: al-Takruri, 1997 [reprint 2003] ), pp.102-79.

19. Johannes Jansen (trans.), The Neglected Duty (New York: Macmillan, 1986); original in 'Abd al-Salam Faraj, al-Farida al-gha'iba (Amman, n.p., n.d.), p. 28; also see trans. Abu Umama, The Absent Obligation (Birmingham: Maktabat al-Ansar, 2000), pp.48-9.

20. For example, see Ayman al-Zawahiri, Shifa' sudur al-mu'minin (n.p., 1996) (written after the EIJ suicide bombing of the Egyptian Embassy in Islamabad, Pakistan); and Rifa'i Ahmad Taha, Imatat al-litham 'an ba'd ahkam al-qital at tawhed.ws.

21. For those who said yes (such as Abu Qatada al-Filistini), see 'Abd al-Malik al-Jaza'iri, Takhlis al-'ibad min wahshiyyat Abi al-Qatad al-da'i ila qatl al-niswan wa-faladhat al-akbad: nasihat abi Qatada al-Filistini al-mufti bi-irhab al-Muslimin wa-ghayrihim bi-qatl nisa'ihim wa-atfalihim wa-jawaz akhd amwalihim (Cairo: Dar Madad, 2005).

22. Ayman al-Zawahiri, al-Tabri'a (al-Sahab, 2007), p. 201, available at http://www.e-prism.org/ images/kitab_al-Tabrieah_-_2-3-08.pdf.

23. See his journal al-Jihad (years 1984-1986).

24. See his "Martyrs: The Building Blocks of Nations" (from azzam.com) and his comments in al-Jihad 15 (October 1985), pp.38-39, “al-Shahid wa-l-shahada: al-halqa al-thalatha."

25. Sulaym al-Silafi, al-Fawa'id al-hisan min hadith Thawban (tada'i al-umam) (Casablanca: Dar Ibn 'Affan, 2001), pp.7-14 gives full references.

26. Note the brief statement of al-Khumayni in this regard: Masa'il jihadiyya (Beirut: al-Wahda al-Islamiyya, 2002), pp.27-8.

27. See the discussion of Robert Pape, Dying to Win (New York: Random House, 2005), pp.129-39, 187-91, and for data appendix 1.

28. Joseph Alagha, "Hizbullah and Martyrdom", Orient 45 (2004), pp.47-74.

29. See the fatwas of Ayatullah 'Ali al-Sistani, Ahdath al-istifta'at al-'aqa'idiyya (Beirut: Dar al-Jawadayn, 2007), pp.379f.

30. See the "Islamic Ruling on the Legitimacy of Martyrdom Operations" which is a translation (abridged) of Yusuf al-'Ayyiri's Hal intaharat Hawa' am ustushihidat? (available at tawhed.ws and at alsunnah.info). Cf. also Ayman al-Zawahiri, in Raymond Ibrahim, ed., "Jihad, Martyrdom, and the Killing of Innocents", The Al Qaeda Reader (New York: Broadway Books, 2007), esp. pp.146-57.

31. Abu al-Bara' al-Najdi, Is 'ad al-akhyar fi ihya' sunnat nahr al-kuffar (at tawhed.ws).

32. Yusuf al-'Ayyiri, Hidayat al-hayari fi jawaz qatl al-asari (at tawhed.ws); and the manual of Abu Qatada al-Shami, Khatf at http:/ / www.e-prism.org/images/alkhatf.pdf.

33. 'Umar 'Abdallah Hasan al-Shaybani, al-Tamthil bi-l-qatala (at tawhed.ws).

34. http://www.e-prism.org/images/PRISM\%20Special\%20dispatch\%20no\%201.doc.

35. Examples are Abu Qatada al-Filistini and Abu Muhammad al-Maqdisi. 
Copyright of Totalitarian Movements \& Political Religions is the property of Routledge and its content may not be copied or emailed to multiple sites or posted to a listserv without the copyright holder's express written permission. However, users may print, download, or email articles for individual use. 